\title{
Merged or omitted? What we know (or don't) about separated mothers who pay or should pay child support in Australia
}

\author{
MARIA VNUK* \\ Doctoral Candidate, Australian Demographic and Social Research Institute, The Australian \\ National University, Canberra, Australia
}

\begin{abstract}
$A$ rapidly changing landscape in the care arrangements of children means that new conceptual lenses are required to understand the many ways in which children are - or are not-supported following parental separation. While research into non-resident fathers has intensified in recent years, studies of non-resident mothers remain in the margins. This article brings to the fore discussions about non-resident mothers and money. It collates the small amount of research in Australia on non-resident mothers and women who pay child support, refers to relevant international studies, and suggests what further research is required. My hope is that this article will stimulate thought and act as a catalyst for more focused work on the potentially complex interactions between gender and post-separation parenting.
\end{abstract}

Keywords: non-custodial mothers; non-resident parents; child support; compliance; enforcement; divorce; children

O hild support research tends to focus on two groups - payers and receivers - often referred to as non-resident and resident parents ${ }^{1}$ Studies that refer to non-resident parents or paying parents are in most cases referring only to fathers. This is because children generally live with their mother after separation, though change is afoot. Female payers are either omitted from the analysis or, if included, findings are not disaggregated by gender. As a result, what we know about child support payment in Australia is predominately based on mothers' reports of payments received from fathers; some research draws on fathers' reports of payments made to mothers or received from mothers; and almost nothing has been published on mothers' reports of payments made to fathers.

\footnotetext{
Correspondence to: mariavnuk@bigpond.com. Maria Vnuk is an employee of the Australian Government Department of Families, Housing, Community Services and Indigenous Affairs. The opinions, comments and/or analysis expressed in this document are those of the author and do not necessarily represent the views of the Minister for Families, Housing, Community Services and Indigenous Affairs or the Australian Government Department of Families, Housing, Community Services and Indigenous Affairs, and cannot be taken in any way as expressions of Australian Government policy.

1 Often studies of child support use a form of the following words to explain omitting atypical arrangements: 'Ninety percent of children with divorced or separated parents live with their mother, so we assume that after the parents separate, the mother obtains custody of the children' (Ermisch, 2008, p. 829).
} 
Not every parent who should pay child support does in fact pay. Policy responses to non compliance are based on men paying and women receiving. This one-sided approach to compliance renders female payers invisible. As Kielty pointed out: 'The failure to consider parental role reversal and the experiences of non-resident mothers implies that, with regard to the 'workability' of post-divorce parenting arrangements, parental gender is not considered to be pertinent' (Kielty, 2005, p. 14). This article (a) collates the small amount of empirical research in Australia on non-resident mothers and women who pay child support, (b) refers to relevant international studies, and (c) explains why and what further research is required.

\section{WHO HAS TO PAY CHILD SUPPORT?}

In Australia, the Child Support Agency (CSA) administers the Child Support Scheme (CSS). In the majority of cases, child support is based on an administrative assessment (i.e., a formula used for assessment by the CSA). The (new) formula in operation since July 2008 is based on an 'income shares' model and uses both parents' incomes (after deduction of a self-support amount) and their level of care to determine the amount payable. In the 'typical' situation, where children are largely in the care of one parent (sole care), the other parent is liable to pay an assessed amount of child support. This payment can be collected by CSA (CSA Collect) or transferred privately between the parents themselves (Private Collect). More than half of CSA cases are transferred privately between parents (Child Support Agency [CSA], 2009, p. 31).
The resident/non-resident parent dichotomy is increasingly less accurate or useful in determining who is a potential payer of child support. In $11 \%$ of child support cases, the care arrangement is other than sole (defined as where children are in the care of one of the parents for $70 \%$ or more nights each year). Both the percentage and numbers of cases that are not sole care are increasing (CSA, 2009, p. 25)2. If newly registered cases are considered rather than all cases, $17 \%$ involve shared care (Smyth, 2009, p. 41). If all the children of the relationship are not in the sole care of one parent, both parents can potentially be the paying parent and the liabilities are offset against each other. The higher income parent usually ends up with a net amount to pay or, if the parents' incomes are similar or both below the self support amount, the liability could be nil. This means that the parent with the 'higher' amount of care or more children in their care is not always the receiving parent. The complexity and fluidity of post separation parenting means that parents can move in and out of the paying parent role depending on changes in their and their former partners' income and/or the level of care of their children.

In order for a parent to receive more than the minimum amount of Family Tax Benefit (FTB) Part A, ${ }^{3}$ they are required to meet the Maintenance Action Test (MAT) by registering their child support case with the CSA. ${ }^{4}$ Coverage of eligible parents by CSA has been estimated to be around 90\% (Australian National Audit Office, 2002, p. 32). Even if actual coverage is not as high as estimated, it is likely that to meet the MAT; most low-to-middle-income resident par-

2 This figure does not include CSA cases involving split care (i.e., siblings in care of different parents) as this information is not included in CSA Facts and Figures 07/08.

3 Family Tax Benefit Part A (FTB) is paid to a parent (or carer) to help in the cost of raising children. To be eligible a parent/carer must have at least 35\% care of a dependent child aged 0-15 (or 16-24 in certain circumstances). The cut-off for payment of more than the base rate of FTB depends on household income and the number and age of all the children in the family. Both the amount payable and the cut-off for the base rate are relatively high. For example, a couple or sole-parent family with two children, one under 12 and the other 13-15 years of age, can have a household income of up to $\$ 78,165$ before they are only paid the base rate of FTB. If their household income is less than $\$ 44,166$, they would receive the maximum amount of FTB of $\$ 10,837$. (This information is available from the Family Assistance Office and is based on 2009 payments and income tests: http://facs.gov.au/internet/fao/faol.nsf/content/payments-ftba-how_much_ftbaless_32485.htm)

4 The MAT requires that a parent seeking government income support must 'take reasonable action' to obtain child support. Reasonable action usually takes the form of registering a case with the CSA. 
ents are in the formal child support system. Separated parents can choose to register with the CSA or make their own arrangements (self administer). 5 It is not known how many higher income parents are not in the formal system or have agreed that no child support needs to be paid. The fact that resident or co-parent fathers, even when they are lone parents, are more likely to be in full-time employment than lone mothers (Australian Bureau of Statistics [ABS], 2007, p. 3) suggests that choice rather than need to meet the MAT influences the decision of some fathers in this group to register or not register with CSA.

When exploring the issue of compliance using existing survey data sources, it needs to be noted that some non-resident or co parent mothers may not be expected to pay child support. Payment of child support relates to whether money is exchanged between parents whether there is a formal arrangement for child support or not. ${ }^{6}$ By contrast, compliance requires a formal arrangement (i.e., CSA assessment, court order, or registered agreement) to be in operation. If the expected payment is made in full then the paying parent is considered compliant with their child support obligations. 7

\section{Paternal inVolvement after SEPARATION IN AUSTRALIA}

A key focus of Australian policy, over the past decade at least, is that both parents are encouraged to remain involved with their children after separation. Indeed, more fathers now have primary or shared care of their children post-separation (i.e., at least $30 \%$ of the time) than in the past. Recent data from a nationally representative survey reported by de Vaus et al. (2009, p. 7) indicate that $27 \%$ of men with children under 18 have shared or primary care of at least one of their children post-separation ${ }^{8}$. The increase in father care in conjunction with the new formula leads to the likelihood that more women will, in the future, be in the position of being the paying parent. In 2006/07, 22\% of children under the age of 18 had a natural parent living elsewhere; $18 \%$ of parents living elsewhere were female compared with $12 \%$ a decade earlier (ABS, 1997 , 2008). An estimated 136,000 children had a mother who lived elsewhere and a further 46,000 children had both parents living elsewhere (ABS, 2008, pp. 26-30).

CSA data indicate that in $12.6 \%$ of all cases, the mother is the paying parent. Of cases registered for the first time in January to June 2008, $23 \%$ involved fathers claiming child support from mothers (Child Support Agency, 2009, p. 31). This meant that 93,432 mothers had a child support liability in 2008. 9 Ten years ago there were only 39,921 mothers who were paying parents; $8 \%$ of the CSA caseload (CSA, 1999). These shifts in care are striking at the population level. Now that almost a quarter of new cases have the mother as the paying parent, it is necessary to explore whether an implicit 'gender blind' approach to child support compliance ${ }^{10}$ remains appropriate.

\section{What WE KNOW: AUSTRALIAN STUDIES OF NON-RESIDENT MOTHERS}

The literature on non-resident mothers in Australia is sparse. Even within this literature there is rarely a mention of child support and even more rarely a reference to mothers as payers. There are

5 For low- or middle-income households, this would mean not meeting the MAT and foregoing more than base rate of FTB; a significant financial disincentive in most cases. Little is known about the self administer group, although it is likely to be primarily resident parents in higher income households.

6 Often this is measured by a simple question such as 'Do you make any payments or pay any child support for (specified child)?' Determining compliance is more complex and requires further exploratory questions.

7 This is, of course, a crude measure of compliance. The question of 'on time' is equally relevant. Further research on more sophisticated measures of compliance has begun in Australia.

8 This figure includes separations from cohabitating relationships as well as legal marriages (de Vaus et al., 2009, p. 2)

9 Some of these mothers may have a nil liability.

10 This point is discussed in more detail in section 7. 
only two studies in Australia that focus solely on non-resident mothers and only one mentions child support. ${ }^{11}$ McMurray (1992) interviewed 43 non-resident mothers in Western Australia to explore the mother-child relationship after separation. Limited finances were reported both as a factor in custody relinquishment and as a difficulty in the mothers' current situation. High child support payments and the rigidity of the system were areas of particular concern (McMurray, 1992, pp. 140-141).

When we turn from the studies of non-resident mothers to child support studies that present findings from the paying parents' perspective, we once again find only a few that reported any data from female payers. Silvey and Birrell (2004) used administrative data to explore the financial circumstances of a cohort of CSA registrants who separated in 1997 and remained in the system until at least 2001. The majority of the analysis was based on male paying parents and female receiving parents. However, some data were given for the 5,023 female payers in the 1997 cohort and for the full 2001 caseload (Silvey \& Birrell, 2004, p. 47). This provides an interesting insight into the financial circumstances of payers by gender.

The researchers found that the median income of female payers was around $\$ A U$ 9,500; median liability at registration was nil, and \$AU 260 in 2001 (reflecting the introduction of a minimum assessment amount in 1999). The income profile of female payers closely resembled that of both male and female receiving parents. Silvey and Birrell suggested that parents in these three groups were predominantly reliant on income support (such as parenting payments or unemployment benefits). By contrast, male payers had median incomes of around $\$ A U$ 20,000 and median liabilities at registration of $\$ A U 1,914$ and $\$ A U$ 1,811 in 2001. If mean rather than median liabil- ity was compared, female payers had a liability of \$AU891 and a debt of \$AU 27. Male payers had a liability of $\$ A U$ 3,361 and a debt of \$AU 819 (Silvey \& Birrell, 2004, p. 47). ${ }^{12}$ The picture of the typical female payer provided by this study was that of a mother on a low income (mainly reliant on income support) with a nil or very low liability and therefore with a nil or low child support debt.

The Evaluation of the Introduction of a $\$ 260$ Minimum Child Support Assessment study conducted for the CSA (Wolffs \& Shallcross, 2000) included responses from 1,500 paying parents with a minimum assessment. ${ }^{13}$ Wolffs and Shallcross $(2000$, p. 28$)$ noted that $15 \%$ of paying parent respondents were female, which was almost double their representation in the CSA caseload overall. 14 The complexity of the minimum assessment cases that had a female payer was illustrated by the $13 \%$ of mothers who had more than one CSA case, compared with only $4 \%$ in the total caseload. Additionally $40 \%$ of the mothers had re partnered - suggesting, according to Wolffs and Shallcross (2000, p. 28) that at least some of the mothers who were liable to pay child support were being supported by a new partner and had little income of their own.

The researchers noted that female payers were slightly less likely than male payers to report that they 'always paid on time' ( $47 \%$ compared with $51 \%)$ and more likely to report they 'never paid' (26\% compared with $21 \%$ ) child support. Affordability (i.e., low capacity to pay) was cited as the reason for non-payment by $43 \%$ of female payers (Wolffs \& Shallcross, 2000, p. 29). As responses were not matched with administrative data and ex-couple dyad data were not used, it cannot be established whether the female payers in this study were less compliant or merely more honest in their recall and responses about non-

11 The other study (Buskens, 2002, 2005) focused mainly on why women leave their husbands and children.

12 Female payers in the full caseload had a slightly lower mean liability and debt. Male payers had a slightly lower mean liability but a somewhat higher debt (Silvey \& Birrell, 2004, p. 47).

13 These respondents were drawn from a random sample of 8,000 paying parents. The study also included 766 receiving parents (Wolffs \& Shallcross, 2000).

14 The sample estimate mirrored the $14 \%$ of minimum assessments in the caseload where the paying parent was female. 
payment. Additionally, as the respondents were payers with the lowest incomes, compliance rates may not generalise to the overall CSA caseload.

More recently, Natalier et al. (2008, p. 33) used data from the Household, Income and Labour Dynamics in Australia (HILDA) survey collected in 2004/05 (Wave 4) to explore the relationship between housing and child support (see also Walter, Hewitt, Natalier, Wulff and Reynolds 2010, this issue). 15 While most of the analysis was not disaggregated by gender of the paying parent, Natalier et al. did note that only $39 \%$ of non-resident mothers reported that they paid child support compared to $78 \%$ of non-resident fathers. All these mothers reported paying an amount below the median amount of child support. The gender difference in payment was found to be statistically significant (Natalier et al., 2008, p. 33). However this information related to payment of child support which is not the same as compliance as outlined above. ${ }^{16}$ In addition, the number of non-resident mothers included in this study was small $(n=36)$ as few women reported they had children living elsewhere. Further, the researchers excluded children in nonparental care and parents who have both resident and non-resident children. This analytic exclusion reduced the pool of potential non-resident mothers. This may have been important as one analysis of HILDA (Wave 1) data suggested that almost half of the non-resident mothers may also have a resident child of that relationship in their care (Parkinson \& Smyth, 2003, p. 4).

The different results for payment of child support by mothers reported by Wolffs and Shallcross (2000) and Natalier et al. (2000) can be explained, at least in part, by the differences in the samples and measurements used. All the participants in the Wolffs and Shallcross study were CSA customers who had a child support assessment, and their responses related to whether they paid the expected amount or not. Mothers with non-resident children in the HILDA sample would have included mothers who were not expected to pay any child support, as well as an unspecified number of mothers who may have had an assessment or agreement to pay. Information was only gathered on what was actually paid.

From these studies, it is clear that there is much complexity surrounding female paying parent cases. Paying parents generally report low incomes and there is often minimal information on actual compliance. Some of these mothers (especially those with a minimum liability) had more than one child support case (i.e., they either owed child support to more than one resident father or were entitled to receive child support themselves for children from another relationship). It would appear that multiple case mothers could potentially be both a paying and a receiving parent, ${ }^{17}$ whereas multiple case fathers would more likely be the paying parent for all their cases. This possible difference has yet to be explored and warrants further investigation to establish whether there is any impact on compliance of having a dual role as paying and receiving parent.

\section{WHAT WE KNOW: KEY INTERNATIONAL STUDIES OF NON- RESIDENT MOTHERS}

Noting the brevity of research in Australia, we might ask whether overseas research can assist in developing a picture of mothers who pay or should pay child support. Recent comprehensive

15 HILDA is a national household-based panel survey which began in 2001. The Wave 1 panel consisted of 7,682 households and 19,914 individuals. Interviews are conducted annually with all adult members of each household. Most importantly, if a family member 'splits off' from his/her original household, the entire new household joins the panel (Headey, 2006, p. viii). This makes HILDA useful for research about post-separation parenting.

16 There are some important caveats: The child support question(s) do not distinguish between situations where no child support is meant to be paid (i.e., no CSA assessment or any private arrangement for child support is in place) and actual non-compliance. This may be one of the reasons that the reported child-support payment rates are lower in HILDA than other data sets.

17 Another possibility is that some mothers may have both resident and non-resident children and only have a child-support arrangement in place for one or none of the children. 
literature reviews of the broader non-resident mother research have been published in the UK (Kielty, 2006) and the USA (Bemiller, 2008).18 The main themes in the literature are from psychology or social work with a focus on the process of leaving ('How could she?') and/or the mother-child relationship. Many of the studies explore how and why women live apart from their children and their adjustment to this and do not include child support. Those that do include child support are predominantly from the USA (Arditti \& Madden-Derdich, 1993; Babcock, 1995, 1998; Bailey \& Zvonkovic, 2003; Becerra \& Ong, 2001; Bemiller, 2005; Benson \& Pasley, 1993; Christensen, Dahl, \& Rettig, 1990; Greif, 1986; Greif \& Emad, 1989; Greif \& Pabst, 1988; Herrerias, 1984, 1995, 2008; Maccoby et al., 1992; Smock \& Manning, 1997; Sousa \& Sorensen, 2006; Stewart, 1999). While the samples sizes for many of the studies are small and not representative and some of the data are quite dated (reporting on women who separated in the 1980s), the overall picture from the US literature is one where mothers are less likely to be ordered to pay child support, and if expected to pay, less likely to do so.

The most comprehensive and most often cited work is the study conducted by Greif and Pabst (1988). Their survey of 517 non-resident mothers provided a useful and detailed analysis - albeit now somewhat dated - of child support from the perspective of mainly white middle class, divorced mothers. The other studies vary in the depth of emphasis on child support, and range from the use of small purposive samples with indepth interviews about specific facets of the nonresident mother experience to the use of large, population based surveys (e.g., National Survey of America's Families [NSAF], 1997).

Non-resident mother research in Canada and the UK has been mainly on the psychological themes mentioned previously without including much examination of child support. Notable exceptions were a personal narrative study in Canada (Gustafson, 2005), which included the researcher's experiences of paying child support; a UK in-depth study of 15 non-resident mothers (Kielty, 2005, 2006, 2008); and passing mentions in case studies from a UK self help book (Hart, 2008).

The main - and indeed often the only - mention of child support in many other studies relates to non-payment of child support by nonresident fathers, threats of custody disputes to reduce child support, and general economic stress. Mothers raised these factors as reasons for 'voluntary' relinquishment of custody in Australian and overseas' studies (e.g., Babcock, 1995; Chesler, 1986; Greif \& Pabst, 1988; Herrerias, 1984; Jackson, 1994; Kielty, 2005; McMurray, 1992; Paskowicz, 1982; Pieterse, 2007). The prevailing implicit assumption is that the 'proper' role is for fathers to pay child support and the focus is on their attempts not to pay.

Another research strand, predominantly legally focused, examines custody decision-making, child-support awards and deviations from guidelines, in particular how mothers are treated when determining the amount of child support payable. Although custody determination is a theme across research in several countries (e.g., USA, Canada, UK, Australia), the other child support related topics are mainly pursued in the USA.

The lack of emphasis on child support in nonresident mother research, with the exception of the USA, reflects the formal child-support systems that operate in different jurisdictions, with the proportion of mothers involved in the formal child support system in Australia closer to the USA situation than that of the UK or Canada. Further exploration of the findings from the international studies may be useful in understanding the behaviour of female payers in Australia (e.g., low incomes, norms of 'mothering', patterns of post-separation parenting). However,

18 Earlier literature reviews (Arditti, 1995; Depner, 1993) covered a few studies of child support. Other literature reviews which included non-resident mothers only referred to child support in relation to non-resident fathers (Thompson \& Laible, 1999; Wilson, 2006). 
there are also some differences that affect the transportability of research findings. One is the stringent welfare regime in the USA which can make it harder for low income mothers to care for their children after separation, leading to a high incidence of non-parental care (i.e., grandparent or other relative care and foster care). ${ }^{19}$

The other issue relates to child support enforcement. Automatic withholding of child support from wages by employers is mandatory on registration in the USA and now covers $70 \%$ of paying parents (Office of Child Support Enforcement 2009), leaving minimal options for individual behaviour to influence compliance. In comparison, in Australia more than half of child support cases registered with the CSA are transferred privately between parents. In the other half of the CSA caseload, only 39\% of payments are collected via wage deductions with most of the other parents expected to pay voluntarily 20 (CSA 2009, p. 58). The impact of the wider scope for compliance to be a 'choice' in Australia rather than routinely enforced is an area that requires further research for both male and female payers.

\section{WHAT WE KNOW ABOUT COMPLIANCE BY GENDER}

An important research and policy question to be answered is whether gender or the non-resident/ payer status has more influence on child support payments by mothers. Do women respond in different ways than men to their child support obligations or is there something about the structure of the non-resident or paying parent role that is jointly experienced by both mothers and fathers? If it is the latter, then what is it about this role that is potentially influential? Is it an experience of being or feeling disengaged from your children; being a 'non-resident' ('part-time') parent rather than a ('real') parent. If so, this suggests a deficit approach to post-separation parenting.

Some researchers have suggested the structural aspects of non-resident parenting are influential and that 'there are inherent difficulties in paying money to an ex-spouse...when a parent does not live with, and thus does not have daily contact with his or her children' (Doherty, Kouneski, \& Erickson, 1998, p. 283). Other researchers (Kielty, 2006; Walker \& McGraw, 2000) have noted the potential for a gender difference, reflecting the various paths into non-resident parenting and further noted that we do not know enough to make the comparison. This debate is at an embryonic stage, and requires further research and development of appropriate (gender-sensitive) theoretical frameworks.

Popular media does not seem to portray mothers who do not pay in the same way as fathers' non-compliance. A study of media representations of non-custodial parents in popular US periodicals found that non-support was presented as 'a uniquely male-gendered characteristic' (Clarke, 2004, p. 2). Clarke found that the term 'deadbeat parent' did not 'carry the same emotional weight and severity as 'deadbeat dad'... 'deadbeat' suggests a failure to live up to what is often considered the primary role of the father that of breadwinner and provider' (2000, p. 10). Non custodial mothers who failed to pay child support were rarely referred to as 'deadbeat moms' during the period under review (Clarke, 2004, p. 11). 21

Few reports are available on actual compliance by gender. The limited findings on child support

19 In one nationally representative survey, 39\% of non-resident mothers reported that their child lived with a relative (Sousa \& Sorensen 2006:3). Motivation to pay child support to a non-parental carer may be somewhat different. In addition, child support remains payable in the USA even when children are in foster care and payment is often vigorously pursued as the money collected goes directly to the government to reimburse the costs of foster care (Hatcher, 2009).

20 Some paying parents may have requested wage deductions to make regular payment easier, so this figure is not solely those parents that have deductions as an enforcement measure.

21 But in Australia, see Smyth and Weston (2005, p. 28) for an apparent 'backlash' against non-resident mothers as non-payers of child support. On this point, Smyth and Weston noted that 'society expects mothers to be the main nurturers and carers of children - not the main breadwinner'. 
compliance based on non-resident parents' reports have been discussed in section 3. In general, the child support studies that have sufficient statistical power to detail findings by gender use reports of potential receivers rather than payers. Research based on the latest census data from the USA found that non-resident mothers were less likely to have an order or agreement to pay child support; $40 \%$ of resident fathers and $57 \%$ of resident mothers had a child support award in 2007. Although fewer mothers than fathers paid all the support due, the difference in child support compliance between fathers and mothers was not statistically significant: $47 \%$ of resident mothers and $45 \%$ of resident fathers with a child-support award reported that they received their full payment in 2007.22 Non-payment was also more common among non resident mothers than non-resident fathers: $26 \%$ of resident fathers reported that they received none of the child support due compared to $23 \%$ of resident mothers (Grall, 2009).

Stewart (2004) used data from a large, nationally representative survey 23 - the NSAF (1997) to compare the involvement of non-resident mothers and non-resident fathers. This study looked at contact and child support compliance based on responses from the 'most knowledgeable adult' 24 , rather than the non-resident parent. The NSAF included child support data for children in both parental and non-parental care. Stewart, (2004, p. 21) found that non-resident fathers were more likely to pay than non-resident mothers were when the child was in the other parent's care (as opposed to non-parental care, such as a grandparent); the rate of reported receipt ranged from $54-61 \%$ for households with a resident mother and $26-34 \%$ for households with a resi- dent father depending on whether the receiving parent had re-partnered. Receipt of child support by households with non-parental carers was lower overall. In only $21-34 \%$ of these households, child support was received from the non-resident father; non-resident mothers appeared more likely to 'pick up the slack' in these situations with rates of receipt for grandparents and other carers ranging from 29-39\% (Stewart, 2004, p. 21). Stewart found that there was still a difference between non-resident fathers and non-resident mothers when the analysis was restricted to payments based on child support ordered payment only (i.e., child support compliance), but did not show these results in her paper (Stewart, 2004, p.18). Sousa and Sorensen (2006) using the 2002 wave of the NSAF and non-resident parents' reports found that $63 \%$ of fathers and $44 \%$ of mothers paid some child support. (This included parents who did not have a formal award.) The researchers noted that payment was a function of having an order for child support. As this information was not available for some of the non-resident parent sample, their analysis of child support compliance, like that of Stewart (2004), was based on resident parents' reports. Only 37\% of resident fathers with an order received a payment compared to $54 \%$ of resident mothers (Sousa \& Sorensen, 2006, p. 2). ${ }^{25}$

\section{What we know about compliance by gender in Australia}

Twenty years ago, few fathers were in receipt of any child support in Australia. Of course, many would say that few mothers were in receipt of any child support too. In 1987, prior to the introduction of the Child Support Scheme, only 1.5\% of

22 Census data from the Current Population Survey - Child Support Supplement only surveys resident parents and not nonparental carers.

23 This survey had 2,293 children with a non-resident mother (Stewart, 2004).

24 The 'most knowledgeable adult' might not be the potential child support recipient and therefore may not have full information about child support payments made into the household.

25 The differences between the payment rates for resident fathers and mothers found in the large, nationally representative surveys (Sousa \& Sorensen, 2006; Stewart, 2004) and the Census data could relate to what is being measured (i.e., any payment compared with full payment). In addition, the NSAF only asks about court ordered support and therefore misses those parents who have an agreement to pay child support. The Census asks about all types of child support agreements (Sorensen \& Zibma, 2000, p.14). 
male Sole Parent Benefit recipients reported any child maintenance income, although receipt by mothers was also low at 20-25\% (Raymond, 1987, p. 59). An early Australian study by Funder (1993, p. 177) did not include father care cases, although she did note that when children lived with their father, 'little maintenance was paid, and more contact with the non-resident parent was maintained'. 26

Later studies of separated/divorced parents included reports from non-resident as well as resident parents' reports, accepting the need to include both perspectives to have a fuller understanding of child support. Non-resident reports were, in the main, fathers' reports ${ }^{27}$. Some research included, but did not analyse female payers separately (e.g., Headey, Funder, \& Smyth, 1998), while another study omitted the $2 \%$ of women who reported that they paid child support (see Weston \& Smyth, 2000). Two recent studies had small numbers of non-resident mothers $(n=37$ $\& 33$ ) and therefore could only reported on resident mothers and fathers and non-resident fathers. The Caring for Children after Parental Separation study 28 found that non-resident fathers were twice as likely to pay child support as nonresident mothers (Smyth \& Weston, 2005, p. 28). In the General Population of Parents Survey (2006) $2946 \%$ of resident fathers and $66 \%$ of resident mothers reported receiving child support payments (Qu \& Weston, 2008, p. 28).30
Some further information, based only on resident parents' reports, comes from the ABS (1997) Family Characteristics Survey. 31 Customised tables from the 2003 survey showed $23 \%$ of resident fathers received child support compared to $62 \%$ of resident mothers $(\mathrm{Qu} \&$ Weston, 2008, p. 28). Although the numbers of non-resident mothers in these two studies were too small to do any further analysis, the findings (and those of resident parents by the ABS) suggest that child support is less likely to be paid when the father is the resident parent. Whether this relates to a lower expectation that mothers should pay child support or lower compliance with liabilities requires further investigation. In the US, it has been suggested by Stewart (1999, p. 905) that the use of cross-sectional data could be less useful for the study of non-resident mothers because of the dynamic and less permanent nature of the arrangement. The major Australian longitudinal surveys, such as the Longitudinal Study of Australia Children (LSAC) and HILDA, are of limited utility for research on female payers and child support until the numbers become large enough to allow meaningful analysis. 32

The number of resident fathers in HILDA, although still small, is slightly higher than non-resident mothers, therefore some comparison between resident fathers and resident mothers has been reported (although the same caveats about HILDA noted above apply). Acknowledging the

26 This study and the majority of the studies cited below have been conducted by the Australian Institute of Family Studies (AIFS).

27 The few non-resident mother studies are reported in section 3.

28 This study comprised 'a national random sample of 455 male and 572 female parents who had a least one child under the age of 18 years and who were not living with the other parent of that child. Most of the parents had been divorced (72\%), $23 \%$ had been cohabiting and 5\% had never lived with the other parent' $\mathrm{Qu}, 2004, \mathrm{p} .4)$.

29 The General Population of Parents Survey (GPPS) was a nationally representative sample of 5,000 parents with a child under 18 years old conducted in June/July 2006 (Qu \& Weston, 2008, p. 32).

30 The reported compliance rate was higher in the GPPS than in some other surveys. For example, resident parents' reports in HILDA showed low rates of receipt for both resident mothers (49\%) and resident fathers (18\%). The authors noted that the difference in the questions asked across surveys (GPPS, HILDA and FCS) may affect responses (Qu \& Weston, 2008, p. 28).

31 The last official release of ABS data on child support was in 1997, as there were some concerns with the 2003 child support data; only customised data are available. Child support questions were not asked in the latest survey, Family Characteristics and Transitions Australia 2006-07.

32 It is unlikely that LSAC will be useful as less than $1 \%$ of the children in LSAC (Wave 2) lived in lone father or stepmother families (Baxter, Qu, \& Weston, 2007) giving a very small pool of non-resident mothers as potential respondents for the Parent Living Elsewhere survey. 
very small numbers once the data are further divided into lone and re-partnered resident parents, only $1 \%$ of fathers in blended families, $4 \%$ of fathers in stepmother families and $16 \%$ of lone fathers reported receiving payment from their child's mother. 33 While these figures seem extremely low, without further questions that clarify whether child support is meant to be paid, comparisons about compliance between mothers and fathers are not meaningful. Although some data from resident parents' reports have been included in studies of post separation parenting, the author is not aware of any specific Australian studies that focus on lone fathers or stepmother families and child support.

Official compliance data are limited in Australia. The Child Support Agency only reports on CSA Collect cases and these data are not disaggregated by gender. A media report of CSA debt in 2008 stated that 25,000 women had a child support debt; 10,000 owed more than AU\$340 and 14,700 had a smaller debt (Packham, 2008). Based on the numbers of payers in the total CSA caseload, this equated to $27 \%$ of mothers with a debt compared with $35 \%$ of fathers. These figures need to be examined in context. This was a point in time release of child support debt and therefore is only indicative of compliance by gender. Further, in calculating percentages for the total caseload the CSA assumes that Private Collect cases are $100 \%$ compliant. As private transfers are more common when the mother is the paying parent (53\%) than the father (48\%) (CSA, 2009, p. $31)^{34}$, this assumption is particularly pertinent.

\section{What WE KNOW: ReAsONS FOR FATHERS' COMPLIANCE}

There is a significant body of international research on fathers' child support compliance behaviour as well as a few Australian studies. ${ }^{35}$ One Australian study (Blamey \& Sutton, 1999, p. 29), using CSA administrative data and paying parents' reports, found the following factors influenced compliance for CSA Collect male paying parents: ability to pay and perceived affordability; 'access' and the perceived risk of losing 'access'; and the quality of the relationship between the parents. ${ }^{36}$ What is known about whether these factors are also relevant for female payers remains at a rudimentary level and warrants further investigation.

It can be hypothesised that the 'ability to pay' child support (as a function of income and employment) is likely to be a factor in compliance for female payers. According to ABS data on parents who had a child living elsewhere, $7 \%$ of the mothers were unemployed and $29 \%$ were not in the labour force. In comparison, $5 \%$ of the fathers were unemployed and $13 \%$ not in the labour force. In addition, $28 \%$ of mothers who live apart from at least one of their children were lone parents themselves (ABS 2008, p.9). It can be expected that many of these lone mothers would be reliant on income support. Evidence from the research by Silvey and Birrell (2004) and Wolffs and Shallcross (2000) suggested a high rate of government income support receipt among female payers. Lower average earnings for women may also be relevant for employed female payers. The issues of how relative 'affordability' affects female payers who have higher incomes and shared care, or those mothers on low incomes who have to pay child support to high income resident fathers, need to be explored - especially in the context of rising rates of shared parenting after separation.

The amount of time spent with children after separation (often referred to as 'access' or 'visita-

\footnotetext{
33 The comparable figures for resident mothers were $26 \%, 39 \%$ and $47 \%$. Other support such as school fees were received by $1 \%$ of fathers in blended families, $4 \%$ in stepmother families and by $9 \%$ of lone fathers. The comparable figures for mothers ranged from 5-24\%. Some parents received both regular and other support (de Vaus, 2004, p. 62).

34 These figures are based on my calculations using CSA data on gender of paying parent (CSA, 2009, p. 31). This estimate does not include the $1 \%$ of CSA cases where the gender of the paying parent is unknown.

35 A full review of the voluntary compliance literature is available from the author upon request.

36 The findings in this study only refer to CSA Collect cases. Very little is known about compliance behaviour and motivation to pay in the Private Collect group.
} 
tion' and referred to for a period of time in Australia as 'contact') is another factor to be tested. Some researchers have suggested that mothers who live apart from their children remain more in contact by phone and have more daytime and overnight stays with their children than fathers typically do (e.g., Aquilino 1994; Furstenberg et al., 1983; Gunnoe \& Hetherington, 2004; Halle, 2002; Hetherington \& Kelly, 2002; Santrock \& Warshak, 1979). The scant Australian data, albeit based on small numbers, lends support to this finding. Data from HILDA (Waves 1-4) suggested that the median frequency of contact with children was weekly for lone non-resident mothers, fortnightly for lone non-resident fathers, and three-monthly for partnered non-resident parents (Headey, Warren, \& Harding, 2006). Of those non-resident parents who had their children stay overnight, mothers (both lone and partnered) had a higher average number of nights with their children than non-resident fathers (Headey, Warren, \& Harding, 2006, p. 17). ${ }^{37}$

Payment of child support and time spent with children have been found to be positively related for non-resident fathers but in the few studies where this has been examined for both non resident fathers' and non-resident mothers' reports, no relationship was found for mothers (Stewart, 1999, p. 903). One Australian study, using resident parents' reports from the 1997 ABS Family Characteristics Survey, found the reverse relationship between receipt of child support and overnight stays for lone resident fathers. The authors tentatively suggested this finding was related to the better financial circumstances in lone father households (Smyth \& Ferro, 2002, p. 58). Further research is required on the links, if any, between time and money for female payers. The so-called 'access-maintenance' nexus remains a hot issue for policy. Indeed one of the variously considered policy responses to increase child support compliance has been to introduce strategies to facilitate contact arrangements and/or enforce existing parenting plans and court orders.

Blamey and Sutton (1999) suggested that the quality of the parental relationship had an impact on the compliance of male payers. This makes intuitive sense. Many studies have found the quality of the relationship between the parents to be a major factor in successful post-separation parenting. It is likely, although not yet tested, that the parental relationship would also have an impact on the compliance of female payers. Related issues to be examined include the varied pathways into father care and share care (e.g., are a higher proportion of these made by court order rather than agreement?) and the impact of repartnering and new children in the household.

\section{Other factors to be explored}

In addition to the possible predictors of compliance already discussed, there are other factors that warrant investigation. Children mainly in the care of their father are likely to have spent at least some time in their mother's care. Qu (2004, p. 5) found that $10 \%$ of children lived with their father at separation rising to $14 \%$ at the later interview. Older children were more likely to be in father care than younger children; $22 \%$ of 15-17 year olds lived with their father. In addition, $19 \%$ of mothers and $27 \%$ of the fathers with two or more children had different living arrangements $(\mathrm{Qu}, 2004$, p. 5) There would be few female payers who had never, or only briefly, lived with their child, whereas the male paying parent group includes unmarried fathers who may never have lived with their child's mother. It remains to be tested whether - if at all - the length of time in mother care influences compliance for female paying parents.

Other research areas to be explored include the meaning of 'mothering' for female payers and whether mothers who have some of their children still in their care, or subsequent children, respond

37 The average number of overnight stays (of children who stayed overnight) was 85 for mothers who had not re-partnered and 67 for fathers who had not re-partnered; partnered mothers averaged 58 nights and partnered fathers 51 (Headey et al., 2006, p. 17). The authors warn that the estimate for re-partnered mothers is not reliable. 
differently to mothers who live apart from all their children. For some fathers, the 'father' role is highly salient and financial responsibility is accepted as an important component of this role (Henley \& Pasley 2005). Do female payers see financial responsibility as a key component of the mother role and, if not, how does this influence compliance?

\section{WHERE TO FROM HERE?}

It is important to understand the factors that influence voluntary compliance and how, if at all, they vary by gender. If mothers have different compliance rates and motivation for payment or non-payment to fathers, different policy responses are likely to be required. The omission of mothers who pay or should pay from the discussion on compliance has been more by default than as a result of deliberate action. As described previously, it has been difficult to test possible relationships between child support compliance and gender and/or payer role because the numbers of non-resident mothers in datasets have been too small for analysis other than at a basic level. But even in the USA, much of the analysis comparing the compliance of non resident father and non resident mothers using large, national representative data have not used non-resident mothers' reports (e.g., Stewart 2004).

The availability of 'second generation' research datasets - such as the Child Support Reform Study (CSRS) 38- that are both current (2008 data) and have a reasonable number of female payers (or potential payers) will finally allow some of the research questions outlined above to be explored. The CSRS has been described as a 'second generation' study because of its 'breadth, depth and statistical power' (Smyth 2009, p. 53).

In the same way that non-resident fathers' voices were 'missing' from post-separation research until recently, it is now time to hear the voices of non-resident mothers and mothers who pay child support. Smyth, in his discussion of post-separation fathering, argued that there is value in studying 'special populations' - those parents 'at the margins of the most common post-separation family types and issues' (Smyth 2004, p. 38). This is because, as noted by Smyth (2004, p. 2), 'sometimes what lies at the margins can be important for [understanding] what happens at the centre'.

Now that almost a quarter of new cases registered with the Child Support Agency have the mother as the paying parent, it is necessary to explore whether an implicit gender blind approach to child support compliance remains appropriate. I use the phrase gender blind rather than gender neutral, because the latter implies some purposive action. A gender blind approach continues to locate gender differences in compliance behaviour in the margins despite the potential importance of such differences for understanding compliance behaviour from a range of perspectives. It is to be hoped that the availability of next generation Australian studies can begin to address this research gap and increase our knowledge of the key predictors of child support compliance for female payers. This line of inquiry is not merely academic - it has important implications for the wellbeing of children.

The preceding review suggests that non-resident mothers in Australia are less likely to pay child support than non-resident fathers. The reason(s) for this is an important policy question to be answered 39 - particularly in light of the recent shift towards stronger enforcement initiatives in Australia and elsewhere (e.g., Ludwig, 2008). This article is predicated on the idea that a rapid-

38 The CSRS was conducted by the Australian National University in collaboration with the Department of Families, Housing, Community Services and Indigenous Affairs (FaHCSIA) and the Child Support Agency (CSA). Its main purpose was to provide baseline data for monitoring the recent child support reforms. It was conducted between March and May 2008, and involved the collection of data from 'a stratified random sample of over 5,000 separated parents registered with the CSA. The research design includes an over-sample of almost 2,000 shared care cases. Respondents will be followed over time' (Smyth. 2009, p. 53). The longitudinal component of the study will be run in 2009 and 2010 and is funded by an Australian Research Council Linkage Grant between ANU, FaHCSIA and CSA (Smyth, 2009, p. 53).

39 This is the topic of the author's current doctoral dissertation. 
ly changing landscape in the care arrangements of children means that new conceptual lenses are required to understand the many ways in which children are - or are not - supported following parental separation. My intention is that this article might serve to stimulate thought and act as a catalyst for more focused work on the potentially complex interactions between gender and postseparation parenting.

\section{ACKNOWLEDGEMENTS}

I am grateful to Bruce Smyth and two anonymous reviewers for comments on an early draft of this article. Any shortcomings and errors, of course, are mine alone.

\section{References}

Aquilino, W. (1994). Impact of childhood family disruption on young adults' relationships with parents. Journal of Marriage and the Family, 56(2), 295-313.

Arditti, J. A. (1995). Noncustodial Parents: Emergent issues of diversity and process. Marriage \& Family Review, 20(1), 283 - 304.

Arditti, J. A., \& Madden-Derdich, D. A. (1993). Noncustodial mothers: Developing strategies of support. Family Relations, 42(3), 305-314.

Australian Bureau of Statistics (1997). Family Characteristics. Retrieved 20 September 2009. from http://www.abs.gov.au/ausstats/abs@.nsf/Product sbyReleaseDate/168FA461C552DDC9CA256F 16007C45A4? OpenDocument.

Australian Bureau of Statistics (2007). One-Parent Families Retrieved 12 December 2009. from http://www.abs.gov.au/AUSSTATS/abs@.nsf/0/F 4B15709EC89CB1ECA25732C002079B2?ope ndocument.

Australian Bureau of Statistics (2008). Family Characteristics and Transitions, Australia 2006-07. Retrieved 20 September 2008. from http://www.abs.gov.au/AUSSTATS/abs@.nsf/mf /4442.0.

Australian National Audit Office (2002). Client Service in the Child Support Agency Follow-up Audit (No. 9). Canberra: Australian National Audit Office.

Babcock, G. M. (1995). Long Distance Mothers: Attributions and Consequences of Nonresidential Mothering. Unpublished thesis, Washington State University.
Babcock, G. M. (1998). Stigma, identity dissonance, and the nonresidential mother. Journal of Divorce \& Remarriage, 28(1), 139-156.

Bailey, S. J., \& Zvonkovic, A. M. (2003). Parenting after divorce. Journal of Divorce \& Remarriage, 39(3), 59-80.

Baxter, J., Qu, L., \& Weston, R. (2007). Family Structure, Quality of the Co-parental Relationship, Post-separation Parenting and Children's Socioeconomic Wellbeing. Paper presented at the Inaugural Longitudinal Study of Australian Children Conference. Retrieved 20 September 2009, from http://www.aifs.gov.au/growingup/ conf/2007/papers/RuthWeston.pdf

Becerra, R., \& Ong, P. (2001). The Noncustodial Parent: Employment, Earnings, Child Support, Parenting. California: The Ralph and Goldy Lewis Center for Regional Policy Studies.

Bemiller, M. (2005). Mothering on the Margins: The Experience of Noncustodial Mothers. Unpublished thesis, University of Akron.

Bemiller, M. (2008). Non-custodial mothers: Thematic trends and future directions. Sociology Compass, 2/3, 910-924.

Benson, A., \& Pasley, K. (1993). The effects of child support receipt and payment on stepfamily satisfaction: An exploratory study. Journal of Divorce \& Remarriage, 19(3), 197-220.

Blamey, R., \& Sutton, T. (1999). Social Marketing and Regulatory Compliance. Paper presented at the Innovations in Social Marketing Conference.

Buskens, P. (2002). From perfect housewife to fishnet stockings and not quite back again. One mother's story of leaving home. Journal of the Association for Research on Mothering, 4(1), 33-45.

Buskens, P. (2005). When Eve left the garden. A modern tale about mothers who leave their families. In M. Porter, P. Short \& A. O’Reilly (Eds.), Motherhood. Power and Oppression (pp. 265-283). Toronto: Women's Press.

Chesler, P. (1986). Mothers on Trial. New York: McGraw Hill.

Child Support Agency. (1999). Child Support Scheme Facts and Figures 1997-98. Canberra: Child Support Agency.

Child Support Agency. (2009). Facts and Figures 07/08. Retrieved 20 September 2009. from http://www.csa.gov.au/publications/pdf/FactsAn dFigures2008.pdf.

Christensen, D. H., Dahl, C., \& Rettig, K. (1990). Noncustodial mothers and child support: Examining the larger context. Family Relations, 39, 388-394. 
Merged or omitted? What we know (or don't) about separated mothers who pay or should pay child support

Clarke, A. (2004). From Deadbeat Dad to Bio Dad: Media Portrayals of Non-custodial Parent Responsibility from 1960 to 2002. Paper presented at the American Sociological Association Annual Meeting. de Vaus, D. (2004). Step and blended families. In D. De Vaus (Ed.), Diversity and Change in Australian Families (pp. 60-64). Melbourne: AIFS. de Vaus, D., Gray, M., Qu, L., \& Stanton, D. (2009). The effect of relationship breakdown on income and social exclusion. Paper presented at the Australian Social Policy Conference from http://www.aifs. gov.au/institute/pubs/papers/2009/devauspres.pdf

Depner, C. E. (1993). Parental role reversal. Mothers as nonresidential parents. In C. E. Depner \& J. H. Bray (Eds.), Nonresidential Parenting. New Vistas in Family Living (pp. 3757). Thousand Oaks CA: Sage.

Doherty, W. J., Kouneski, E. F., \& Erickson, M. F. (1998). Responsible fathering: An overview and conceptual framework. Journal of Marriage and the Family, 60(2), 277-292.

Ermisch, J. (2008). Child support and non-resident fathers' contact with their children Journal of Population Economics, 21, 827-853.

Funder, K. (1993). Exploring the access-maintenance nexus. In K. Funder, M. Harrison, \& R. Weston (Eds.), Settling down: Pathways of parents after divorce (pp. 175-191). Melbourne, Victoria: AIFS Monograph 13, Australian Institute of Family Studies.

Furstenberg, F. F., Jr., Nord, C. W., Peterson, J. L., \& Zill, N. (1983). The life course of children of divorce: Marital disruption and parental contact. American Sociological Review, 48(5), 656-668.

Grall, T. (2009). Custodial Mothers and Fathers and Their Child Support: 2007. Washington: US Census Bureau,.

Greif, G. (1986). Mothers without custody and child support. Family Relations, 35, 87-93.

Greif, G., \& Emad, F. (1989). A longitudinal examination of mothers without custody: Implication for treatment. The American Journal of Family Therapy, 17(2), 155-163.

Greif, G., \& Pabst, M. (1988). Mothers without custody. Lexington MA: Lexington Books.

Gunnoe, M. L., \& Hetherington, E. M. (2004). Stepchildren's perceptions of noncustodial mothers and noncustodial fathers: Differences in socioemotional involvement and associations with adolescent adjustment problems. Journal of Family Psychology, 18(4), 555-563.

Gustafson, D. (2005). The social construction of maternal absence. In D. Gustafson (Ed.),
Unbecoming Mothers: The Social Production of Maternal Absence (pp. 23-50). New York:

Haworth Clinical Practice Press.

Halle, T. (2002). Charting Parenthood. A Statistical

Portrait of Fathers and Mothers in America.

Washington: Child Trends.

Hart, S. (2008). A Mother Apart. Carmarthen,

Wales: Crown House.

Hatcher, D. L. (2009). Collateral children. Consequences and illegality at the intersection of foster care and child support. Brooklyn Law Review, $74(4), 1-48$.

Headey, B. (2006). Introduction to the First Annual Statistical Report on HILDA In B. Headey, D. Warren \& G. Harding (Eds.), Families, Incomes and Jobs: A Statistical Report of the HILDA Survey (pp. vii-ix). Melbourne: Melbourne Institute of Applied Economics and Social Research.

Headey, B., Funder, K., \& Smyth, B. (1998). Child Support: Which Methods of Collection Work Well and Which Don't? Paper presented at the 6th Australian Institute of Family Studies Conference

Headey, B., Warren, D., \& Harding, G. (2006). Contact between non-resident parents and their children. In B. Headey, D. Warren \& G. Harding (Eds.), Families, Incomes and Jobs: A Statistical Report of the HILDA Survey (pp. 1618). Melbourne: Melbourne Institute of Applied Economic Research.

Henley, K., \& Pasley, K. (2005). Conditions affecting the association between father identity and father involvement. Fathering, 3, 59-80.

Herrerias, C. (1984). Noncustodial Mothers: A Study of Self-concept and Social Interactions Unpublished thesis, University of Texas, Austin.

Herrerias, C. (1995). Noncustodial mothers following divorce. Marriage and Family Review, 20(1/2), 233-255.

Herrerias, C. (2008). Inequities faced by noncustodial mothers. Journal of Interdisciplinary Feminist Thought, 3(1), Article 3:1-25

Hetherington, E. M., \& Kelly, J. (2002). For Better or Worse. Divorce Reconsidered New York: W.W. Norton \& Co.

Jackson, R. (1994). Mothers Who Leave. Behind the Myth of Women Without Their Children. London: Pandora.

Kielty, S. (2005). Mothers are non-resident parents too: A consideration of mother's perspectives on non-residential parenthood. Journal of Social Welfare and Family Law, 27(1), 1 - 16.

Kielty, S. (2006). Similarities and differences in the experiences of non-resident mothers and non- 
resident fathers. International Journal of Law, Policy and the Family, 20, 74-94.

Kielty, S. (2008). Non-resident motherhood: Managing a threatened identity. Child \& Family Social Work, 13(1), 32-40.

Ludwig, J. (2008, 23 June). Minister unveils tough new program to collect child support [media release]. Retrieved. from

http://www.humanservices.gov.au/dhs/media/arc hives/ludwig/08/0806/080623-minister-unveilstough-new-program.html.

Maccoby, E. E., Mnookin, R. H., Depner, C. E., \& Peters, H. E. (1992). Dividing the Child. Social and Legal Dilemmas of Custody. Cambridge MA: Harvard University Press.

McMurray, A. (1992). Influences on parent-child relationships in non-custodial mothers. Australian Journal of Marriage and Family, 13(3), 138-147.

Natalier, K., Walter, M., Wulff, M., Reynolds, M., \& Hewitt, B. (2008). Child Support and Housing Outcomes (No. 113). Melbourne: Australian Housing and Urban Research Institute, Southern Research Centre.

Office of Child Support Enforcement. (2009). Fact Sheet - Collecting. Retrieved 20 September 2009. from http://www.acf.hhs.gov/opa/fact_ sheets/cse_factsheet.html\#collecting.

Packham, B. (2008, 10 December ). Deadbeat mums under scrutiny. Herald Sun, p. 15,

Parkinson, P., \& Smyth, B. (2003). When the Difference is night and day: Some empirical insights into patterns of parent-child contact after separation. Paper presented at the 8th Australian Institute of Family Studies Conference. Retrieved 20 September 2009, from http://www.aifs.gov.au/ institute/afrc8/parkinson.pdf

Paskowicz, P. (1982). Absentee Mothers. New York: Universe Books.

Pieterse, J. T. (2007). Parenting from a distance: Illuminating the lived experiences of nonresident divorced mothers Unpublished thesis, University of Witwatersrand, Johannesburg.

$\mathrm{Qu}, \mathrm{L}$. (2004). Children's living arrangements after separation. Family Matters 67, 4-7.

Qu, L., \& Weston, R. (2008). Snapshots of Family Relationships. Melbourne: Australian Institute of Family Studies.

Raymond, J. (1987). Bringing Up Children Alone: Policies for Sole Parents. Canberra: Department of Social Security.

Santrock, J., \& Warshak, R. (1979). Father custody and social development in boys and girls. Journal of Social Issues, 35(4), 112-125.
Silvey, J., \& Birrell, B. (2004). Financial outcomes for parents after separation People and Place, 12(1), 45-56.

Smock, P. J., \& Manning, W. D. (1997). Nonresident parents' characteristics and child support. Journal of Marriage and the Family, 59(4), 798-808.

Smyth, B. (2004). Post separation fathering: What does Australian research tell us? Journal of Family Studies, 10(1), 20-49.

Smyth, B. (2009). A 5-year retrospective of postseparation shared care research in Australia. Journal of Family Studies, 15(1), 36-59.

Smyth, B., \& Ferro, A. (2002). When the difference is night and day. Parent-child contact after separation. Family Matters 63, 54-59.

Smyth, B., \& Weston, R. (2005). A Snapshot of Contemporary Attitudes to Child Support.

Melbourne: Australian Institute of Family Studies.

Smyth, B., \& Wolcott, I. (2004). Food and family transitions: Cooking in the aftermath of divorce. Journal of the Home Economics Institute of Australia, 11(3), 2-8.

Sorensen, E., \& Zibman, C. (2000). To What Extent Do Children Benefit from Child Support? (No. Discussion Paper 99-11) Washington: Urban Institute.

Sousa, L., \& Sorensen, E. (2006). The Economic Reality of Nonresident Mothers and Their Children, Washington: The Urban Institute.

Stewart, S. (1999). Nonresident mothers' and fathers' social contact with children. Journal of Marriage and the Family, 61, 894-907.

Stewart, S. (2004). Children with Non-resident Parents: Living Arrangements, Visitation and Child Support Paper presented at the American Sociological Association Annual Meeting.

Thompson, R., \& Laible, D. (1999). Noncustodial parents. In M. E. Lamb (Ed.), Parenting and Child Development in Nontraditional Families (pp. 103-123). Mahwah NJ: Lawrence Erlbaum.

Walker, A. J., \& McGraw, L. A. (2000). Who is responsible for responsible fathering? Journal of Marriage and the Family, 62(2), 563-569.

Weston, R., \& Smyth, B. (2000). Financial living standards after divorce. Family Matters 55, 11-15.

Wilson, G. (2006). The non-resident parental role for separated fathers: A review. International Journal of Law, Policy and the Family, 20, 286-317.

Wolffs, T., \& Shallcross, L. (2000). Low income parents paying child support. Evaluation of the introduction of a $\$ 260$ minimum child support assessment. Family Matters, 57, 26-33. 
Reproduced with permission of the copyright owner. Further reproduction prohibited without permission. 